\title{
Structure and Catalytic Function of Re-Oxo Species Grafted onto H-MFI Zeolite by Sublimation of $\mathrm{Re}_{2} \mathrm{O}_{7}$
}

\author{
Howard S. Lacheen, Paul J. Cordeiro, and Enrique Iglesia* \\ Department of Chemical Engineering, University of California at Berkeley, 103 Gilman Hall, \\ Berkeley, California 94720
}

Received August 10, 2006; E-mail: iglesia@berkeley.edu

The formation of single-site heterogeneous catalysts remains a formidable challenge. ${ }^{1}$ Sites with uniform structure and catalytic function seldom prevail in microporous inorganic solids prepared by aqueous exchange of high-valent cations because of the size and charge of aqueous metal-oxo oligomeric precursors and their diverse structures at conditions of $\mathrm{pH}$ and temperature consistent with the structural integrity of aluminosilicates. Anchoring of highvalent metal-oxo species leads to structures that are less reducible than the corresponding bulk oxides and to relatively unreactive oxidation catalysts. ${ }^{2}$ Here, we report the exchange of isolated and uniform $\mathrm{Re}^{7+}$-oxo cations of significant catalytic relevance for oxidation of alcohols via reactions of $\mathrm{Re}_{2} \mathrm{O}_{7}(\mathrm{~g})$ with acidic protons in H-MFI. The structure and catalytic function of these species do not depend on Re content, a hallmark of single-site catalysts with isolated and uniform active sites.

$\mathrm{Re}_{2} \mathrm{O}_{7}$ and organometallic Re-oxo species form volatile species at conditions required for oxidation catalysis. As a result, they cannot be used for oxidation reactions at elevated temperatures despite their high reactivity in alkene epoxidation. ${ }^{3} \mathrm{Re}_{2} \mathrm{O}_{7}, \mathrm{NH}_{4}$ $\mathrm{ReO}_{4}$, and MTO (methyltrioxorhenium) have been grafted onto several inorganic oxide supports in order to stabilize active sites and allow their use as catalysts. ${ }^{3,4}$ The structures of $\mathrm{ReO}_{x}$ species during synthesis, thermal treatment, and catalysis, and even their presence at exchange sites in H-MFI, remain uncertain.

Raman spectra were used to probe the structure of Re-oxo species in H-MFI (Figure 1) after removing fluorescing compounds using a novel UV irradiation treatment (Supporting Information). Raman spectra for $\mathrm{Re}_{2} \mathrm{O}_{7} / \mathrm{H}-\mathrm{MFI}\left(0.4 \mathrm{Re} / \mathrm{Al}_{\mathrm{f}}\right)$ mixtures resembled those for crystalline $\operatorname{Re}_{2} \mathrm{O}_{7} 6,7$ before thermal treatment. $\mathrm{Re}_{2} \mathrm{O}_{7}$ bands disappeared during treatment in dry air at $823 \mathrm{~K}$ for samples with $\mathrm{Re} / \mathrm{Al}_{\mathrm{f}}$ ratios of $0.3-0.8$; broad bands emerged concurrently at 1020 , 980 , and $347 \mathrm{~cm}^{-1}$, similar to those for $\mathrm{ReO}_{4}{ }^{-}$(aq), but shifted to slightly higher frequencies, consistent with the formation of $\mathrm{Si}-$ $\mathrm{O}_{\mathrm{f}} \mathrm{ReO}_{3}-\mathrm{Al}\left(\mathrm{O}_{\mathrm{f}}\right.$ is framework $\left.\mathrm{O}\right)$ centers distorted from perfect tetrahedra. Changes in local $\mathrm{Re}-\mathrm{O}$ coordination upon heating $\mathrm{Re}_{2} \mathrm{O}_{7} / \mathrm{H}$-MFI were also evident in $\mathrm{Re} \mathrm{L}_{\mathrm{I}}$ edge X-ray absorption spectra (Figure 2A). The intensity of the pre-edge feature increased after treatment at $723 \mathrm{~K}$ in dry air because of an increase in the tetrahedral character of $\mathrm{Re}$ centers as in distorted tetrahedral $\mathrm{NH}_{4}$ $\mathrm{ReO}_{4}$, compared with $\mathrm{Re}_{2} \mathrm{O}_{7}$, in which $50 \%$ of the $\mathrm{Re}$ exhibits distorted octahedral symmetry.

Metal-oxo cations with $\mathrm{M}^{7+}$ centers can exist as either monomers (Structure I, Scheme 1) or dimers (Structure II) at exchange sites. Dimers might resemble a distorted $C_{2 v}$ symmetry with two bridging $\mathrm{O}$ atoms and two terminal $\mathrm{Re}=\mathrm{O}$ bonds at each $\mathrm{Re}$ center as depicted in Scheme 1; there are, however, no precedents for di$\mu$-O linkages in $\mathrm{Re}$-oxo complexes. $\mathrm{Re}-\mathrm{O}-\mathrm{Re}$ stretches in dimers, expected at 456 and $185 \mathrm{~cm}^{-1}$ (from bands in molten ditetrahedral $\left.\mathrm{Re}_{2} \mathrm{O}_{7}(\mathrm{l})\right)$, ${ }^{6}$ were not detected after thermal treatment of $\mathrm{Re}_{2} \mathrm{O}_{7} / \mathrm{H}$ MFI mixtures. Bridging $\mu$-O bands in metal-oxo clusters on $\mathrm{Al}_{2} \mathrm{O}_{3}$

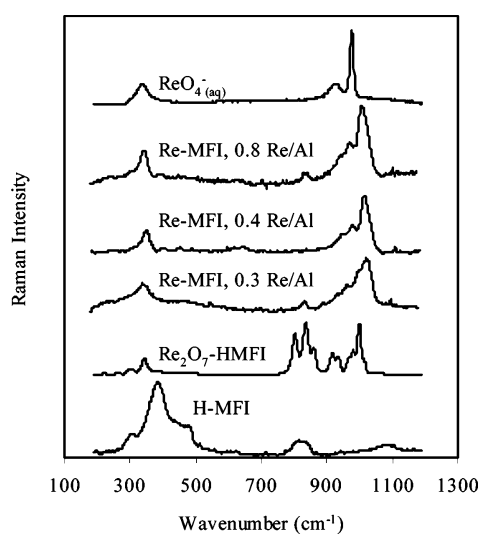

Figure 1. Raman spectra of Re-MFI (MFI background subtracted) and rhenium reference compounds.
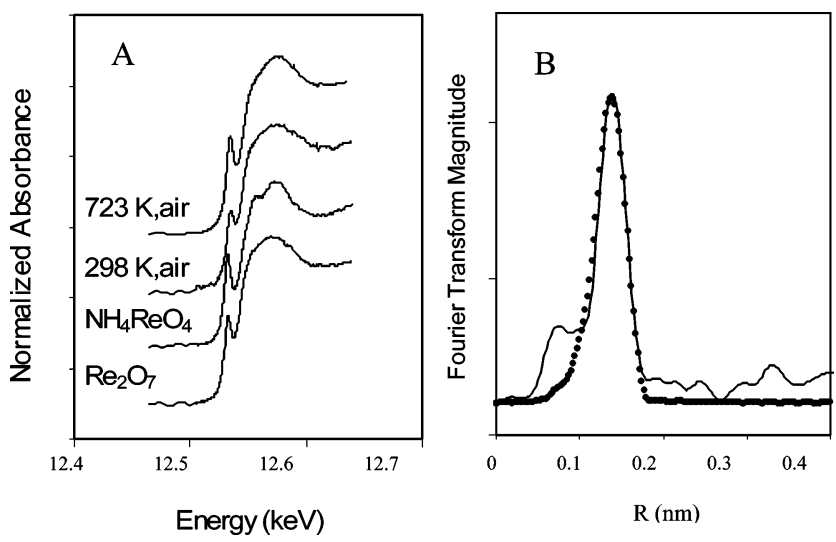

Figure 2. $\mathrm{Re} \mathrm{L}_{\mathrm{I}} \mathrm{X}$-ray absorption spectra of $\mathrm{Re}_{2} \mathrm{O}_{7}, \mathrm{NH}_{4} \mathrm{ReO}_{4}$, and $\mathrm{Re}_{2} \mathrm{O}_{7} /$ $\mathrm{H}-\mathrm{MFI}\left(\mathrm{Re} / \mathrm{Al}_{\mathrm{f}}=0.2\right)$ at 298 and $723 \mathrm{~K}(\mathrm{~A})$. $\mathrm{Re} \mathrm{L}_{\mathrm{III}}$ radial structure function (B) of Re-MFI $\left(\mathrm{Re} / \mathrm{Al}_{\mathrm{f}}=0.2\right)$ after treatment at $773 \mathrm{~K}$ in dry air (solid line). Simulation results shown as circles.

are weak, however, because of nonuniform coordination; ${ }^{2}$ thus, we cannot exclude the coexistence of Structures I and II from the absence of these bands. Extended X-ray absorption fine structure (Figure $2 \mathrm{~B}$ ) for Re-MFI $\left(\mathrm{Re} / \mathrm{Al}_{\mathrm{f}}=0.2\right)$ also did not detect $\mathrm{Re}-$ $\mathrm{O}-\mathrm{Re}$ bonds, expected in Re-oxo dimers. A fit of the spectra gave two $\mathrm{Re}-\mathrm{O}$ shells with coordination of 3 and 1 at 0.17 and 0.18 $\mathrm{nm}$, respectively, without the second shell expected for $\mathrm{Re}-\mathrm{O}-$ Re structures.

The isolated and accessible nature of grafted $\mathrm{ReO}_{x}$ species was confirmed by Raman shifts detected upon exposing samples to weakly coordinating $\mathrm{H}_{2} \mathrm{O}$ molecules. Bands shifted to lower frequencies for $\mathrm{ReO}_{x}$ on $\mathrm{Al}_{2} \mathrm{O}_{3}$ but not for $\mathrm{NH}_{4} \mathrm{ReO}_{4}$ (s) crystals with inaccessible $\mathrm{Re}^{7+}$ centers. ${ }^{8}$ The symmetric $\mathrm{Re}-\mathrm{O}$ stretch in Re-MFI shifted to $975 \mathrm{~cm}^{-1}$ upon contact with $\mathrm{H}_{2} \mathrm{O}(\mathrm{g})(3 \mathrm{kPa})$ at ambient temperature. The antisymmetric $\left(941 \mathrm{~cm}^{-1}\right)$ and bending 
Scheme 1. $\mathrm{Re}_{2} \mathrm{O}_{7}(\mathrm{~g})$ Exchange Pathways

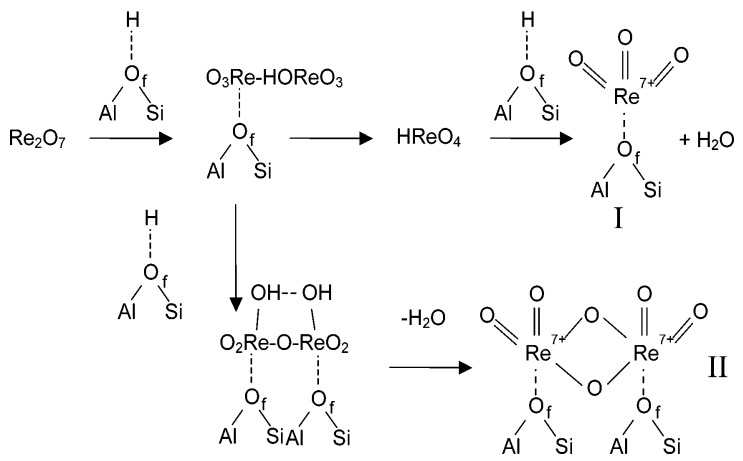

$\left(334 \mathrm{~cm}^{-1}\right)$ modes also shifted to lower frequencies. In $\mathrm{Re}_{2} \mathrm{O}_{7} / \mathrm{Al}_{2} \mathrm{O}_{3}$, exposure to ambient air gave spectra identical to those of $\mathrm{ReO}_{4}{ }^{-}$(aq) $\left(970,919\right.$, and $\left.332 \mathrm{~cm}^{-1}\right),{ }^{6}$ but Re-MFI gave bands that were higher in energy. These shifts indicate that all tetrahedral Re-oxo centers are accessible and distorted by coordination with $\mathrm{H}_{2} \mathrm{O}$.

The Re-oxo exchange stoichiometry was measured from the number of $\mathrm{OH}$ groups detected in the infrared spectra of samples before and after exchange with $\mathrm{Re}_{2} \mathrm{O}_{7}(\mathrm{~g})$ at several $\mathrm{Re} / \mathrm{Al}_{\mathrm{f}}$ ratios. Infrared bands for acidic $\mathrm{Si}-\mathrm{OH}-\mathrm{Al}$ and $\mathrm{Si}-\mathrm{OH}$ silanols are present in $\mathrm{H}-\mathrm{MFI}$, but silanols are minority species. Differences in $\mathrm{OH}$ band intensities $\left(3400-3700 \mathrm{~cm}^{-1}\right)$ between Re-MFI and $\mathrm{H}-\mathrm{MFI}$ samples treated at $673 \mathrm{~K}$ reflect the number of $\mathrm{OH}$ groups replaced by $\mathrm{Re}$ during exchange. The intensity of $\mathrm{OH}$ bands decreased linearly with increasing $\mathrm{Re} / \mathrm{Al}_{\mathrm{f}}$ ratio: 0.25 and $0.5 \mathrm{OH} /$ $\mathrm{Al}_{\mathrm{f}}$ were replaced with 0.22 and $0.44 \mathrm{Re} / \mathrm{Al}_{\mathrm{f}}$, respectively. Thus $1.1 \mathrm{H}^{+}$are replaced by each $\mathrm{ReO}_{x}$ cation at both $\mathrm{Re}$ contents, consistent with either monomer or dimer Re-oxo species (Scheme 1 ), but not with unexchanged or crystalline $\mathrm{ReO}_{x}$.

$\mathrm{Si}-\mathrm{O}_{\mathrm{f}} \mathrm{ReO}_{3}-\mathrm{Al}$ monomers can form via reaction of $\mathrm{Re}_{2} \mathrm{O}_{7}(\mathrm{~g})$ with $\mathrm{Si}-\mathrm{O}_{\mathrm{f}} \mathrm{H}-\mathrm{Al}$ groups to form $\mathrm{Si}-\mathrm{O}_{\mathrm{f}} \mathrm{Re}_{2} \mathrm{O}_{6}(\mathrm{OH})-\mathrm{Al}$, which then decomposes into $\mathrm{Si}-\mathrm{O}_{\mathrm{f}} \mathrm{ReO}_{3}-\mathrm{Al}$ and volatile perrhenic acid (Scheme 1). ${ }^{9} \mathrm{HReO}_{4}(\mathrm{~g})$ can react with neighboring $\mathrm{Si}-\mathrm{O}_{\mathrm{f}} \mathrm{H}-\mathrm{Al}$ groups to form another $\mathrm{Si}-\mathrm{O}_{\mathrm{f}} \mathrm{ReO}_{3}-\mathrm{Al}$ and $\mathrm{H}_{2} \mathrm{O}(\mathrm{g})$. Re-MFI with $\mathrm{Re} / \mathrm{Al}_{\mathrm{f}}$ ratios above 0.5 could not be synthesized reproducibly (only about $60 \%$ of the $\mathrm{OH}$ groups reacted even for $\mathrm{Re} / \mathrm{Al}_{\mathrm{f}}$ ratios of unity), apparently because two monomers at next nearest neighbor $\mathrm{Al}$ sites sublime in the presence of trace amounts of $\mathrm{H}_{2} \mathrm{O}$ ubiquitous in $\mathrm{H}-\mathrm{MFI}$ samples. Reduction in $\mathrm{H}_{2}$ formed $2.8 \pm 0.1 \mathrm{H}_{2} \mathrm{O}$ per $\mathrm{Re}$ and consumed $3.4 \pm 0.1 \mathrm{H}_{2}$ per $\mathrm{Re}$ for $0.1-0.44 \mathrm{Re} / \mathrm{Al}_{\mathrm{f}}$. The heptavalent nature of the $\mathrm{Re}$ centers, the proposed exchange pathways, and the prevalence of grafted $\mathrm{Si}-\mathrm{O}_{\mathrm{f}} \mathrm{ReO}_{3}-\mathrm{Al}$ monomers are consistent with the dynamics and stoichiometry of their reduction in $\mathrm{H}_{2} \cdot{ }^{10}$

Rates and selectivities for ethanol oxidation were measured on Re-MFI samples with $\mathrm{Re} / \mathrm{Al}_{\mathrm{f}}$ ratios of 0.1 and $0.4 . \mathrm{C}_{2} \mathrm{H}_{5} \mathrm{OH}-\mathrm{O}_{2}$ reactions formed ethyl acetate $\left(\mathrm{CH}_{3} \mathrm{CH}_{2} \mathrm{OCOCH}_{3}\right)$ and acetal $\left(\left(\mathrm{CH}_{3}-\right.\right.$ $\left.\mathrm{CH}_{2} \mathrm{O}\right)_{2} \mathrm{CHCH}_{3}$ ) via secondary reactions of primary acetaldehyde $\left(\mathrm{CH}_{3} \mathrm{CHO}\right)$ products. ${ }^{11} \mathrm{Re}-\mathrm{MFI}$ contains both redox sites $\left(\mathrm{ReO}_{x}\right)$ and Brønsted acid sites ( $\mathrm{Si}-\mathrm{OH}-\mathrm{Al})$. Oxidative dehydrogenation turnover rates at $373 \mathrm{~K}$ were $2.2 \times 10^{-3}$ and $2.3 \times 10^{-3} \mathrm{~mol}$ $\mathrm{C}_{2} \mathrm{H}_{5} \mathrm{OH}(\mathrm{mol} \mathrm{Re})^{-1} \mathrm{~s}^{-1}$ on Re-MFI materials with 0.1 and 0.4 $\mathrm{Re} / \mathrm{Al}_{\mathrm{f}}$ ratios, respectively; no catalyst deactivation or $\mathrm{ReO}_{x}$ sublimation was detected during reaction (for $\sim 12 \mathrm{~h}$ ). These findings indicate that the reactivity of Re-oxo species is independent of Re loading, consistent with the similar structure and stoichiometry shown by Raman and infrared spectra and by their reduction in $\mathrm{H}_{2}$.

Re-MFI showed significant reactivity for acetaldehyde and acetal synthesis with $<1 \% \mathrm{CO}_{2}$ selectivity at much lower temperatures $(373 \mathrm{~K})$ than on previously reported Re-based catalysts $(>573 \mathrm{~K}) .{ }^{12}$
At low $\mathrm{Re} / \mathrm{Al}_{\mathrm{f}}$ ratios $(0.1),\left(\mathrm{C}_{2} \mathrm{H}_{5}\right)_{2} \mathrm{O}$ selectivities were relatively high $(\sim 66 \%)$ because of abundant acidic $\mathrm{OH}$ groups, but $\left(\mathrm{C}_{2} \mathrm{H}_{5}\right)_{2} \mathrm{O}$ selectivity decreased as grafted $\mathrm{ReO}_{x}$ replaced $\mathrm{OH}$ groups $(26.3 \%$ for $0.4 \mathrm{Re} / \mathrm{Al}_{\mathrm{f}}$ ) that catalyze condensation reactions required for acetal synthesis.

This study shows that thermal treatment of $\mathrm{Re}_{2} \mathrm{O}_{7} / \mathrm{H}-\mathrm{MFI}$ mixtures leads to the selective grafting of isolated and stable $\mathrm{Re}$ oxo species via $\mathrm{Re}_{2} \mathrm{O}_{7}(\mathrm{~g})$ reactions with $\mathrm{OH}$ groups to form $\mathrm{Si}-$ $\mathrm{O}_{\mathrm{f}} \mathrm{ReO}_{3}-\mathrm{Al}$ with similar structure irrespective of Re content ( $\mathrm{Re} /$ $\left.\mathrm{Al}_{\mathrm{f}}=0.1-0.4\right)$. These catalysts showed very high reactivity for $\mathrm{C}_{2} \mathrm{H}_{5} \mathrm{OH}$ oxidation, a reaction relevant to the conversion of biomass to fuels and chemicals, with turnover rates independent of $\mathrm{Re}$ content for samples with $0.1-0.4 \mathrm{Re} / \mathrm{Al}_{\mathrm{f}}$ ratio. Grafting onto exchange sites prevented the ubiquitous sublimation of $\mathrm{ReO}_{x}$ species, which previously rendered Re-based materials unsuitable as oxidation catalysts. These materials and the synthetic protocols used here may also lead to novel catalysts for metathesis and epoxidation reactions, as well as to precursors and catalysts for reactions that benefit from spatial constraints within zeolites.

Acknowledgment. These studies were funded in part by BP through the Methane Conversion Cooperative Program. H.L. acknowledges a fellowship from the Ford Foundation and access to facilities in the Berkeley Catalysis Center. X-ray spectra were measured at the Stanford Synchrotron Research Laboratory, a user facility operated by Stanford University on behalf of the U.S. Department of Energy, Office of Basic Energy Sciences.

Supporting Information Available: Experimental methods and extended $\mathrm{C}_{2} \mathrm{H}_{5} \mathrm{OH}$ reaction data. This material is available free of charge via the Internet at http://pubs.acs.org.

\section{References}

(1) (a) Mickittrick, M.; Jones, C. W. J. Am. Chem. Soc. 2004, 126, 3052. (b) Kawabata, T.; Mizugaki, T.; Ebitani, K.; Kaneda, K. J. Am. Chem. Soc. 2003, 125, 10486. (c) Goellner, J. F.; Gates, B. C.; Vayssilov, G. N Rösch, H. J. Am. Chem. Soc. 2000, 112, 8056. (d) Long, R. Q.; Yang, R. T. J. Am. Chem. Soc. 1999, 121, 5595. (e) Groothaert, M. H.; Smeets, P. J.; Sels, B. F.; Jacobs, P. A.; Schoonheyd, R. A. J. Am. Chem. Soc. 2005 127, 1394. (f) Sânchez-Sânchez, M.; Blasco, T. J. Am. Chem. Soc. 2002, $124,3443$.

(2) (a) Asakura, K.; Noguchi, Y.; Iwasawa, Y. J. Phys. Chem. B 1999, 103, 1051. (b) Chen, H. Y.; Sachtler, W. M. H. Catal. Lett. 1998, 50, 125. (c) Ding, W.; Meitzner, G. D.; Marler, D. O.; Iglesia, E. J. Phys. Chem. B 2001, 105, 3928. (d) Lacheen, H. S.; Iglesia, E. J. Phys. Chem. B 2006, 110,5462 .

(3) (a) $0.1 \mathrm{kPa}$ vapor pressure at $496 \mathrm{~K}$; $\mathrm{HReO} 4$ (perrhenic acid) $503 \mathrm{~K}$ b.p., $0.01 \mathrm{kPa}$ v.p. at $298 \mathrm{~K}$. (b) Yuan, Y.; Liu, H.; Imoto, H.; Shido, T.; Iwasawa, Y. J. Catal. 2000, 195, 51. (c) Yuan, Y.; Iwasawa, Y. J. Phys. Chem. B 2002, 106, 4441. (d) Liu, H.; Iglesia, E. J. Phys. Chem. B 2003 107, 10840. (e) Liu, H.; Iglesia, E. J. Catal. 2004, 223, 161. (f) Herrmann, W. A.; Wang, M. Angew. Chem., Int. Ed. Engl. 1991, 30, 1641. (g) Scott, S. L.; Basset, J. M. J. Am. Chem. Soc. 1994, 116, 12069. (h) Zhu, Z.; Espenson, J. H. J. Mol. Catal. A 1997, 121, 139. (i) Viswanadham, N.; Shido, T.; Iwasawa, Y. Appl. Catal. A 2001, 219, 223. (j) Herrmann, W. A.; Fischer, R. W.; Marz, D. W. Angew. Chem., Int. Ed. Engl. 1991, 30, 1638 .

(4) (a) Wang, L.; Ohnishi, R.; Ichikawa, M. J. Catal. 2000, 190, 276. (b) Wang, L.; Ohnishi, R.; Ichikawa, M. Catal. Lett. 1999, 62, 29. (c) Shu, Y.; Ohnishi, R.; Ichikawa, M. Appl. Catal. A 2003, 252, 315.

(5) Borry, R. W.; Kim, Y.-H.; Huffsmith, A.; Reimer, J. A.; Iglesia, E. J. Phys. Chem. B 1999, 103, 5787.

(6) (a) Krebs, B.; Mueller, A.; Beyer, H. H. Chem. Commun. 1968, 5, 263. (b) Hardcastle, F. D.; Wachs, I. E.; Horsley, J. A.; Via, G. H. J. Mol. Catal. 1988, 46, 15. (c) Kim, D. U.; Wachs, I. J. Catal. 1993, 141, 419.

(7) (a) Kerkhof, F. P. J. M.; Moulijn, J. A.; Thomas, R. J. Catal. 1979, 56 , 279. (b) Woodward, L. A.; Roberts, H. L. J. Chem. Soc., Faraday Trans. 1956, 52, 615 .

(8) Wang, L.; Hall, W. K. J. Catal. 1983, 82, 177

(9) Beattie, I. R.; Gilson, T. R.; Jones, P. J. Inorg. Chem. 1996, 35, 1301.

(10) Lacheen, H. S.; Cordeiro, P. J.; Iglesia, E. Chem.-Eur. J. Manuscript in preparation.

(11) Liu, H.; Iglesia, E. J. Phys. Chem. B 2005, 109, 2155.

(12) Harrison, W. T. A.; McManus, A. V. P.; Kaminsky, M. P.; Cheetham, A. K. Chem. Mater. 1993, 5, 1631.

JA065832X 